Article

\title{
Biosynthesis of Bacterial Cellulose/Carboxylic Multi-Walled Carbon Nanotubes for Enzymatic Biofuel Cell Application
}

\author{
Pengfei Lv ${ }^{1}$, Quan Feng ${ }^{2}$, Qingqing Wang ${ }^{1}$, Guohui Li ${ }^{1}$, Dawei Li $^{1}$ and Qufu Wei ${ }^{1, *}$ \\ 1 Key Laboratory of Eco-textiles, Jiangnan University, Wuxi 214122, Jiangsu, China; \\ 6130703014@vip.jiangnan.edu.cn (P.L.); wqq888217@126.com (Q.W.); wykaojn@126.com (G.L.); \\ ldw19900323@163.com (D.L.) \\ 2 Key Laboratory of Textile Fabric, Anhui Polytechnic University, Wuhu 241000, Anhui, China; \\ fengquan@ahpu.edu.cn \\ * Correspondence: qfwei@jiangnan.edu.cn; Tel.: +86-137-7110-6262; Fax: +86-510-8591-3100
}

Academic Editor: Juergen Stampfl

Received: 26 January 2016; Accepted: 7 March 2016; Published: 9 March 2016

\begin{abstract}
Novel nanocomposites comprised of bacterial cellulose (BC) with carboxylic multi-walled carbon nanotubes (c-MWCNTs) incorporated into the BC matrix were prepared through a simple method of biosynthesis. The biocathode and bioanode for the enzyme biological fuel cell (EBFC) were prepared using BC/c-MWCNTs composite injected by laccase (Lac) and glucose oxidase (GOD) with the aid of glutaraldehyde (GA) crosslinking. Biosynthesis of BC/c-MWCNTs composite was characterized by digital photos, scanning electron microscope (SEM), and Fourier Transform Infrared (FTIR). The experimental results indicated the successful incorporation of c-MWCNTs into the $\mathrm{BC}$. The electrochemical and biofuel performance were evaluated by cyclic voltammetry (CV) and linear sweep voltammetry (LSV). The power density and current density of EBFCs were recorded at $32.98 \mu \mathrm{W} / \mathrm{cm}^{3}$ and $0.29 \mathrm{~mA} / \mathrm{cm}^{3}$, respectively. Additionally, the EBFCs also showed acceptable stability. Preliminary tests on double cells indicated that renewable $\mathrm{BC}$ have great potential in the application field of EBFCs.
\end{abstract}

Keywords: bacterial cellulose; carbon nanotubes; laccase; glucose oxidase; enzyme biological fuel cell

\section{Introduction}

More attention has been increasingly paid to eco-friendly materials because of an increased awareness of sustainable development and environmental protection [1]. Nowadays, enzymatic biofuel cells (EBFCs) as the new green energy devices have drawn much attention because they are capable of harvesting electricity from renewable and abundantly available sources by using enzymes as the catalysts for oxidation of biofuels (most commonly, glucose) and reduction of oxidizers (most commonly, oxygen) [2,3]. They are renewable energy without any harmful intermediates and side products. Most EBFCs cathodes involve the four-electron reduction of $\mathrm{O}_{2}$ to water [4].

$$
\mathrm{O}_{2}+4 \mathrm{H}^{+}+4 \mathrm{e}^{-} \rightarrow 2 \mathrm{H}_{2} \mathrm{O}
$$

Due to the fact that active centers of the enzymes are usually buried inside the protein matrix, electron transfer to the electrodes has been of crucial importance for EBFC performance [5]. Many types of carbon nanotubes (CNTs) have, therefore, been widely used as conductive nanowires in facilitating electron transfer from the catalytic centers of enzymes to the electrode surface because of their unique properties of being chemically inert with excellent conductivity, their electro-chemical stability, and molecular dimensions that enable intimate interaction with the enzymes [6-8]. These unique properties 
of CNTs make them extremely attractive for electrochemical applications, protein electrochemistry, electrochemical sensors, and especially for biosensors or biofuel $[9,10]$. In the bioelectronics field, CNTs have been used as supports for enzyme immobilization to enable direct electron transfer because of their large specific surface area and good conductivity [11].

Bacterial cellulose (BC), synthesized by Acetobacter xylinum, is a green, economical, and low-cost biopolymer [12]. As a general material, $\mathrm{BC}$ has distinctive properties including high ultrafine porosity, three-dimentional web-like structure, high crystallinity, water absorbance, mechanical properties, and biocompatibility, which makes it versatile in terms of application in many fields such as paper and paper-based products, audio components, tissue engineering, food, and electronic industries [13,14], as well as stretchable conductors [15], lithium ion battery anodes [16], conductive and fire-resistant aerogels [17]. Furthermore, the hydroxyl groups on its backbone can provide BC with a high hydrophilicity, which is crucial for the operation of polymer electrolyte membrane fuel cells [18]. However, these methods are not convenient to apply because they require additional time consuming, energy-intensive, or expensive steps, such as pyrolization at very high temperatures with the application of curing agents or chemical modification. Post-treatments have been carried out on cellulose to prepare a composite film of cellulose and reduced graphene for applications in supercapacitors [19], and flexible and conductive films [20].

In this work, biosynthesis of BC/carboxylic multi-walled carbon nanotubes (c-MWCNTs) in agitated culture were used as both bioanode and biocathode in EBFCs (Figure 1). The biocathode and bioanode were prepared and the BC/c-MWCNTs were injected with laccase (Lac) and glucose oxidase (GOD) by glutaraldehyde (GA) crosslinking, respectively. This new membrane electrode assemblies (MEAs) method offers theoretical and technological supports for exploiting high-efficient EBFCs.

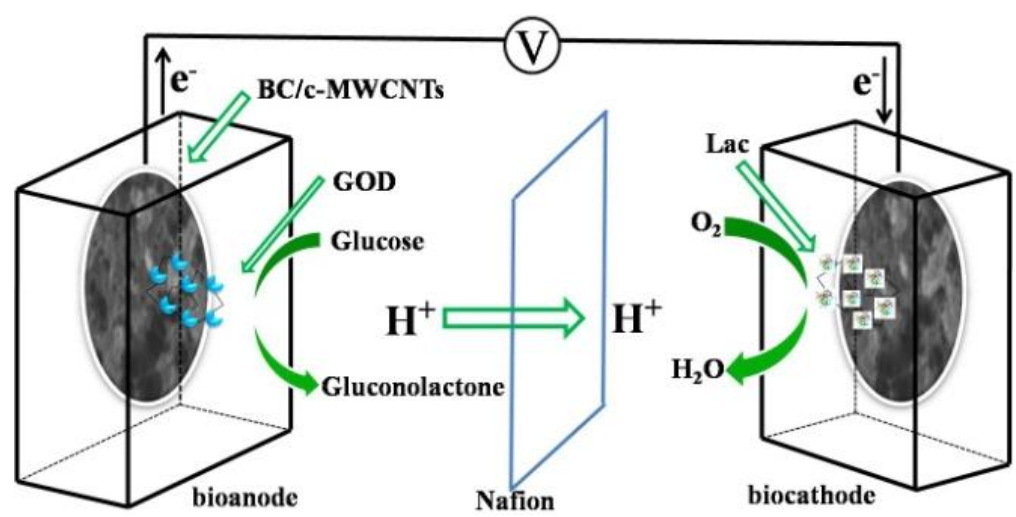

Figure 1. Illustration of the EBFC equipped with 3D BC/c-MWCNTs hybrid electrodes (not to scale).

\section{Experimental Materials and Procedures}

\subsection{Chemicals}

The industrial laccase powder (3 U/mg) from Trametes was purchased from Wuhan Nuohui Pharmaceutical And Chemical Co., Ltd. (Wuhan, Hubei, China); the industrial glucose oxidase ( $800 \mathrm{U} / \mathrm{mg}$ ) was obtained Henan Huakang Chemical Co., Ltd. (Zhenzhou, Henan, China); the c-MWCNTs (OD, $<8 \mathrm{~nm}$; Length, $0.5-2 \mu \mathrm{m}$; Purity, $>95 \%$ ) was supplied by Nanjing XFNANO Materials Tech Co., Ltd. (Nanjing, Jiangsu, China), and glutaraldehyde was purchased from Henan Huakang Chemical Co., Ltd. (Zhenzhou, Henan, China).

\subsection{Preparation of $B C / c-M W C N T$ S Composite}

First, c-MWCNTs were dispersed in culture media containing 2.5\% (w/v) D-mannitol, $0.5 \%(\mathrm{w} / \mathrm{v})$ yeast, $0.3 \%(\mathrm{w} / \mathrm{v})$ bacto-peptone [21]. These culture media were sterilized at $120{ }^{\circ} \mathrm{C}$ in an autoclave for $2 \mathrm{~h}$ and poured into Erlenmeyer flasks. The bacterium was cultured on Hestrin and Schramm 
(HS) $(5 \%(\mathrm{w} / \mathrm{v})$ glucose, $1.6 \%(\mathrm{w} / \mathrm{v})$ bacto-peptone, $0.2 \%(\mathrm{w} / \mathrm{v})$ citric acid, $0.2 \%(\mathrm{w} / \mathrm{v})$ disodium hydrogen phosphate, $0.3 \%(\mathrm{w} / \mathrm{v})$ potassium dihydrogen phosphate, $0.03 \%(\mathrm{w} / \mathrm{v})$ magnesium sulfate) medium [22] by static incubation. The pre-cultured cells in a test tube containing small cellulose particles on the surface of the medium were inoculated into a $100 \mathrm{~mL}$ Erlenmeyer flask containing $10 \mathrm{~mL}$ of the HS medium (in the presence of final $0.01 \mathrm{w} / \mathrm{v} \% \mathrm{c}-\mathrm{MWCNTs}$ in culture media). The flasks were incubated on a rotary shaker operating at rotational speed of $100 \mathrm{rpm}$, for 6 days at $30{ }^{\circ} \mathrm{C}$. The synthesized cellulose was separated from the medium by filtration and were dipped into $1 \%$ sodium hydroxide solution for $2 \mathrm{~h}$ at $80^{\circ} \mathrm{C}$ in order to eliminate the cells and medium embedded in the cellulose material, then rinsed three times to $\mathrm{pH} 7$ in deionized water [23].

\subsection{Preparation of Enzyme Electrode}

The biocathode was prepared by the following method: BC/c-MWCNTs were injected by $40 \mathrm{mg} \mathrm{mL}^{-1} \mathrm{Lac}$ with $1.5 \%(\mathrm{v} / \mathrm{v}) \mathrm{GA}$ in $0.1 \mathrm{M}$ acetic acid/sodium acetate buffer $(\mathrm{pH}=5.5)$ solution for $1 \mathrm{~h}$. The bioanode was prepared by similar method except that the $40 \mathrm{mg} \mathrm{mL}^{-1}$ Lac was replaced by $20 \mathrm{mg} \mathrm{mL}^{-1} \mathrm{GOD}$. Then, the electrode was dipped into $0.1 \mathrm{M}$ acetic acid/sodium acetate buffer $(\mathrm{pH}=5.5)$ solution containing $50 \mathrm{mM}$ glucose, as shown in Figure 2.

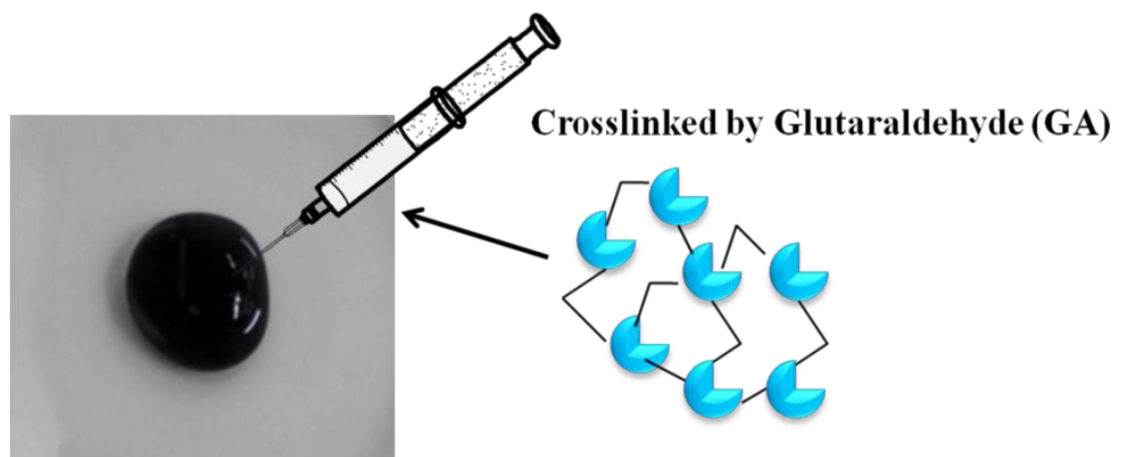

Self-immobilized enzyme slurry

Figure 2. Illustration of the Lac and GOD immobilized on BC/c-MWCNTs by GA crosslinking.

\subsection{Characterization and Electrochemical Measurements}

The morphology of the BC and BC/c-MWCNTs composite membranes surfaces were characterized by field emission scanning electron microscope (FESEM, S-4800, Hitachi, Tokyo, Japan). The morphology of the $\mathrm{BC}$ was also characterized by high-resolution transmission electron microscope (TEM, JEOL/JEM-2100, Tokyo, Japan). Dried BC and BC/c-MWCNTs composite were placed over aluminum support and sputtered with gold. The samples were coated with a thin layer of $\mathrm{Au}$ nanoparticles to reduce the charging effects before FESEM observation.

The pure BC, c-MWCNTs, and BC/c-MWCNTs composite membranes were prepared in $\mathrm{KBr}$ pellet and scanned with Fourier transform infrared spectrophotometer (FTIR, Nicolet NEXUS, Hillsboro, OR, USA).

Electrochemical measurements were performed using a CHI 660D electrochemical workstation (CH Instruments, Inc., Austin, TX, USA). The electrochemical response was measured in a conventional three-electrode system using BC/c-MWCNTs/Lac and BC/c-MWCNTs/GOD as working electrode, a $\mathrm{Pt}$ wire auxiliary electrode and the $\mathrm{Ag} / \mathrm{AgCl}$ as reference electrode. The electrocatalytic activity of bioanode material was tested toward oxygen reduction reaction in $0.1 \mathrm{M}$ sodium acetate/acetic acid buffer solution ( $\mathrm{pH}$ 5.5). The electrochemical measurements were carried out at around $25^{\circ} \mathrm{C}$. 


\section{Results and Discussion}

\subsection{Culture Process Characterization}

Figure 3 illustrates a six-day track of bacterial cellulose growth in presence of c-MWCNTs under agitated culture. Firstly, G. xylinus was inoculated into the culture media contain c-MWCNTs. On the first day, culture solution fully presented black color as shown in Figure 3, but it could be seen that the color faded with the increasing number of days, revealing only a single black bacterial cellulose in the culture solution indicating the incorporation of c-MWCNTs into the bacterial cellulose. On the sixth day, the culture solution became clearer (similar to the original culture color), indicating the incorporation of remaining c-MWCNTs into BC pallet. The sixth day growth of bacterial cellulose in the absence of c-WMCNTs presented a white cryptomere structure.

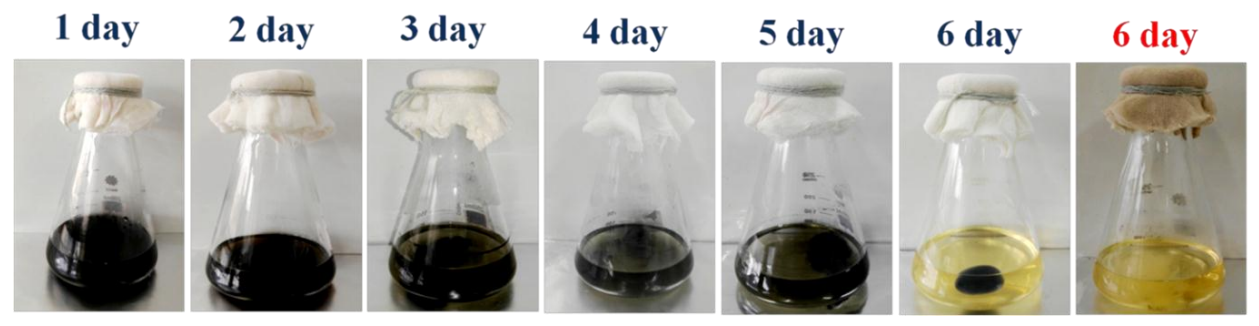

Figure 3. Growth of bacterial cellulose in the presence of c-MWCNTs $(50 \mathrm{mg} / 100 \mathrm{~mL})$ sheets: Photographic image of the six day track of bacterial cellulose growth in presence of c-MWCNTs under agitated conditions. The sixth day growth of bacterial cellulose in the absence of c-MWCNTs (red font).

Figure 4 displays schematic illustration of the formation of bacterial cellulose and the integration of c-MWCNTs into the 3D interconnected fibrous network of BC. Firstly, c-MWCNTs were dispersed into culture solution and then the free bacteria was attached to the surface bubbles which apparently underwent reproduction to synthesize bacterial cellulose fibers [24]. As the days increased, the bacterial cellulose attached itself to the c-MWCNTs to form a more compact structure [25]. Due to the growth of the bacterial cellulose in the presence of c-MWCNTs under agitated conditions, the bacterial cellulose and c-MWCNTs entangled with each other and gradually gathered for the dispersion of c-MWCNTs in culture solution. It was again observed that due to the slow rate of BC-formation, c-MWCNTs was, therefore, absorbed on the $\mathrm{BC}$ whiles the bacteria gathered around the $\mathrm{BC} / \mathrm{c}-\mathrm{MWCNTs}$ composite and produced BC fibrils. The formation of new BC fibrils on existing composite was continuous until a more compact, irregularly shaped, and randomly overlapped composite was obtained.

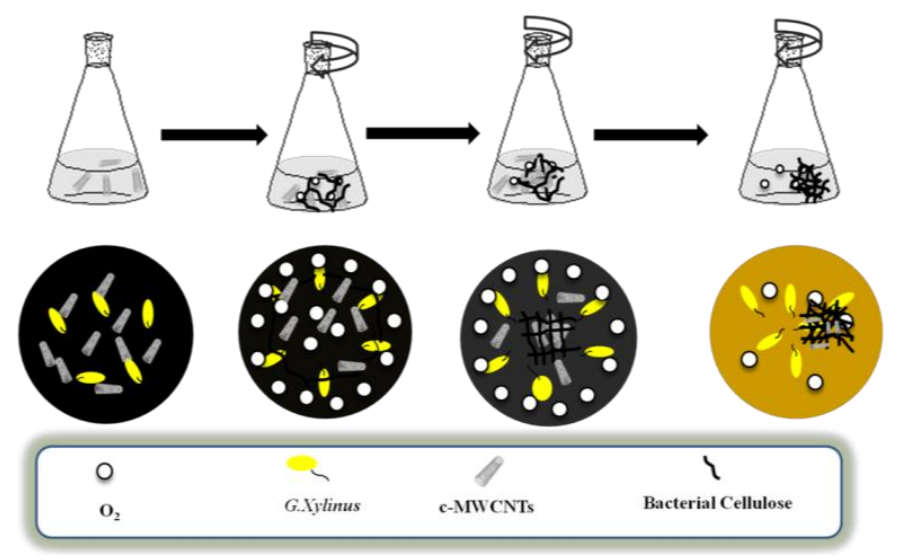

Figure 4. Schematic illustration of formation of bacterial cellulose and the integration of carbon into the 3D interconnected fibrous network of BC. 


\subsection{Morphology Analysis}

The microstructure of BC was characterized by scanning electron microscopy (SEM) and transmission electron microscopy (TEM). Figure 5a shows pure BC fibrils with ultrafine nanofiber structure, high ultrafine porosity 3D web-like structure. As shown in Figure 5a, BC revealed interconnecting pores which is in agreement with the report of refference [26]. The ultrafine network structure and larger specific surface area provided favourable channels for $\mathrm{O}_{2}$ transmission. The high-resolution TEM image further revealed that these nanofibers were mainly consisted of randomly orientated 3D web-like structure (Figure 5b) [27]. Figure 5c showed that c-MWCNTs was absorbed on 3D BC fibrils in which c-MWCNTs displayed the phenomenon of aggregation. As shown in Figure 5d, the morphology of BC/c-MWCNTs samples revealed that c-MWCNTs were tightly wrapped in BC pellicle resulting in an spherical shaped structure.
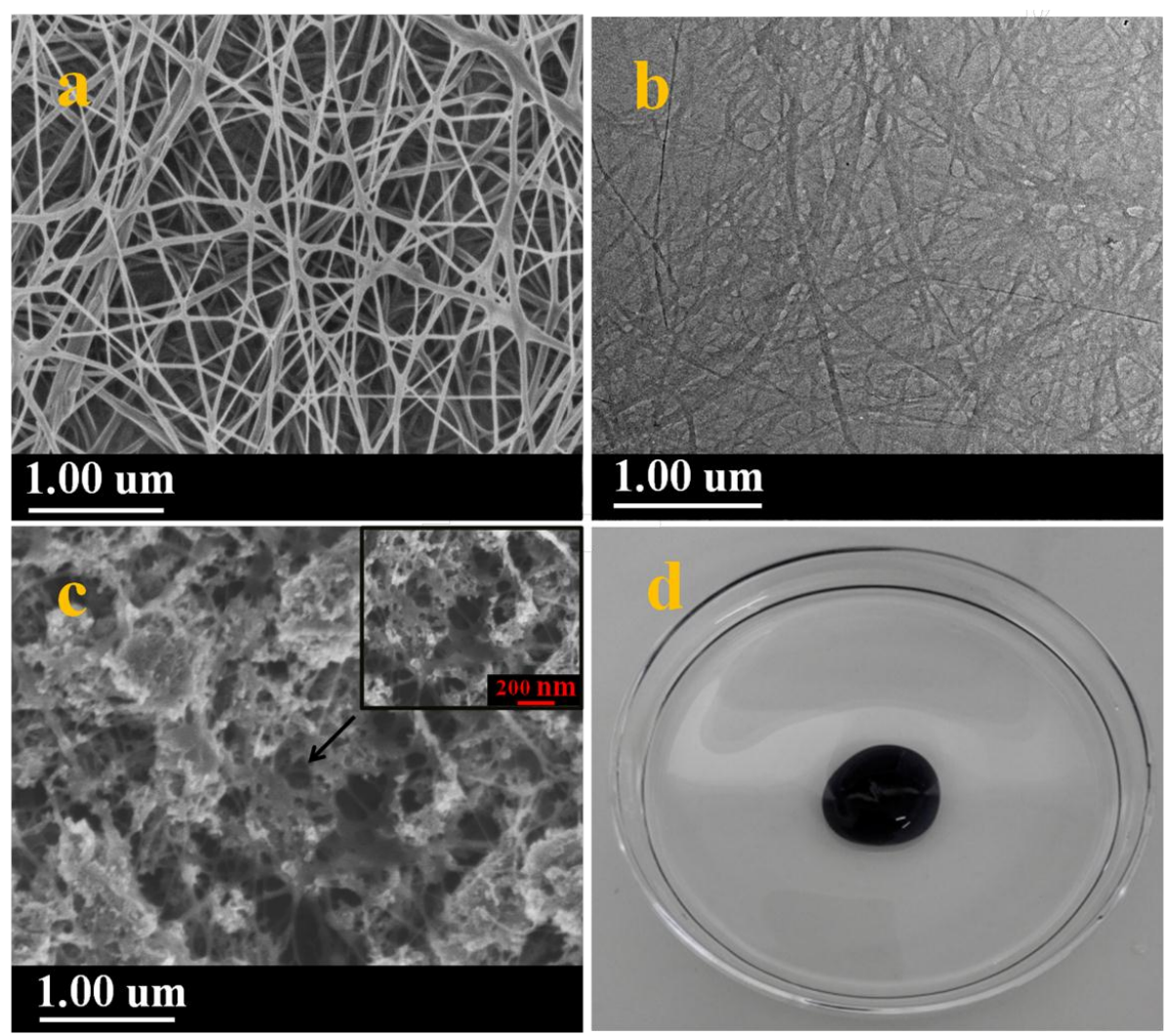

Figure 5. (a) FESEM images of pure BC synthesized in shaking culture system; (b) TEM image of BC; (c) FESEM images of BC/c-MWCNTs composite membranes; and (d) digital photos of c-MWCNTs-dispersed HS medium a shaking culture system at $30^{\circ} \mathrm{C}$ for 6 days $(100 \mathrm{rpm})$.

\subsection{FTIR Analysis}

Figure 6 shows the FT-IR spectra of the pure BC c-MWCNTs and BC/c-MWCNTs. The band at $3465 \mathrm{~cm}^{-1}$ for c-MWCNTs was attributed to the presence of hydroxyl groups(-OH) [28], as shown in Figure $6 \mathrm{~b}$. The absorption band at $1659 \mathrm{~cm}^{-1}$ for c-MWCNTs was assigned to the presence of carboxyl functional groups $(\mathrm{C}=\mathrm{O})$ which was in agreement with references $[29,30]$. The absorption band at $2973 \mathrm{~cm}^{-1}$ for BC (Figure 6a) was also attributed to the presence of $\mathrm{C}-\mathrm{H}$ stretching vibrations which was in agreement with the characteristic bands of $B C$ reported in the literature [31]. The main difference in the spectra of $\mathrm{BC}$ and $\mathrm{BC} / \mathrm{c}-M W C N T s$ was found at the absorption peak of $3465 \mathrm{~cm}^{-1}$, as shown in Figure 6c. The peak at $3465 \mathrm{~cm}^{-1}$ for BC/c-MWCNTs composite membranes were enhanced, suggesting that only physical interaction occurred between BC and c-MWCNTs. 


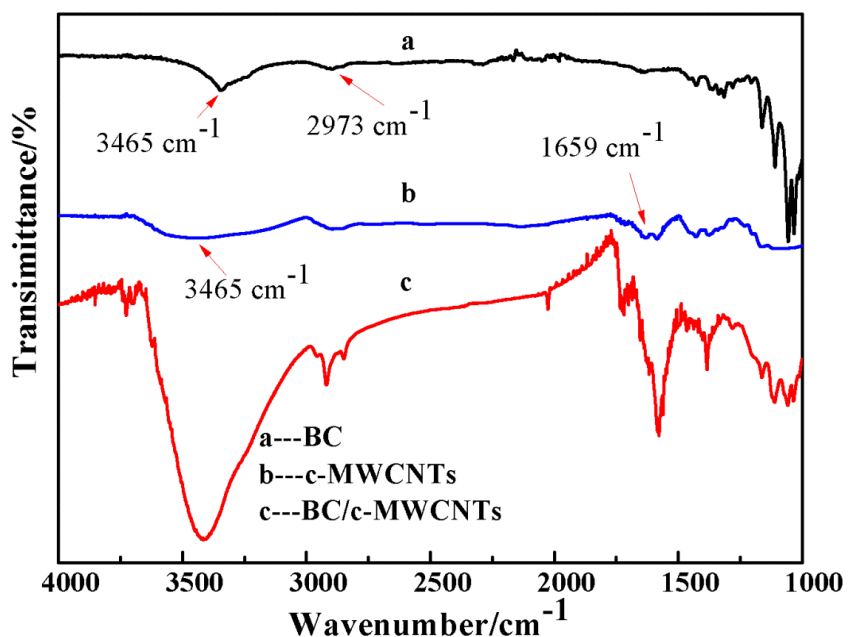

Figure 6. FTIR spectra of different composite. (a) BC; (b) c-MWCNTs; and (c) BC/ c-MWCNTs composite.

\subsection{Effect of Different Conditions on Power Output of the EBFC}

\subsubsection{The Influence of Different Glucose Concentrations}

Figure 7a displays the maximum power output of the EBFC with different glucose concentration ranging from $15 \mathrm{mM}$ to $70 \mathrm{mM}$. Figure 6a shows relatively higher power output in lower concentrations region (15-50 mM); however, when the glucose concentration further increased, the power output greatly decreased. In general, the power output showed a relatively higher enzyme activity among the range of $30-55 \mathrm{mM}$ with an optimum concentration of about $50 \mathrm{mM}$.

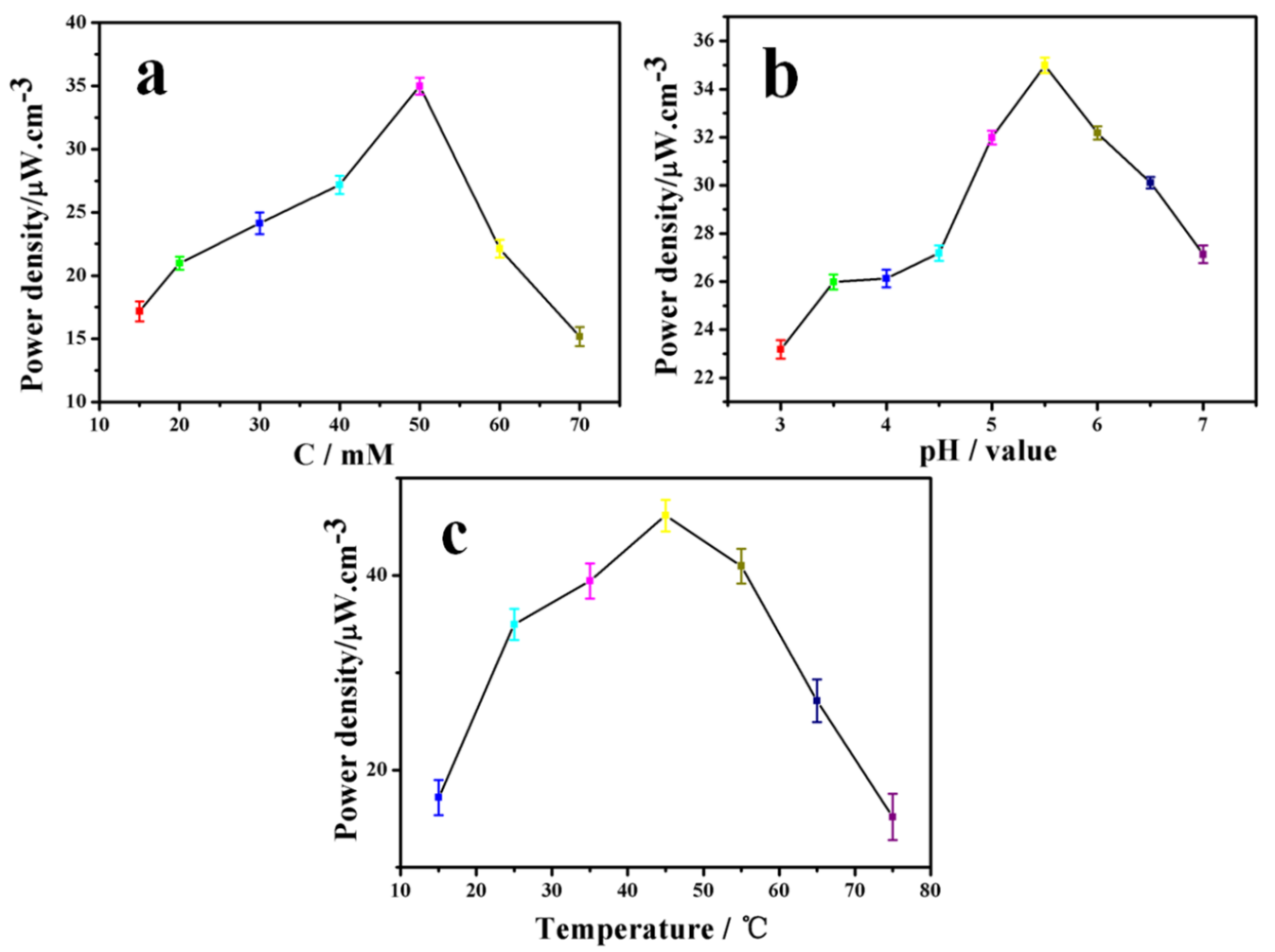

Figure 7. The maximum power output of the EBFC with different conditions: (a) glucose concentrations; (b) optimum $\mathrm{pH}$; and (c) optimum temperature. 


\subsubsection{The Influence of Different $\mathrm{pH}$}

The biofuel cells were incubated in buffer solution with $\mathrm{pH}$ ranging from 3 to 7 at room temperature (Figure $7 \mathrm{~b}$ ). The immobilized laccase and glucose oxidase on BC/c-MWCNTs showed relatively higher $\mathrm{pH}$ stability. Additionally, the immobilized enzyme on $\mathrm{BC} / \mathrm{c}-\mathrm{MWCNTs}$ composite showed a relatively higher activity among the range of $\mathrm{pH} 4-6$, and the optimum $\mathrm{pH}$ was around 5.5, as shown in Figure $7 \mathrm{~b}$.

\subsubsection{The Influence of Different Temperature}

The effect of temperature on power density of immobilized enzyme on BC/c-MWCNTs is shown in Figure 7c. The immobilized enzyme was incubated in buffer solution (pH 5.5) for 5 min at different temperatures varying from 15 to $75^{\circ} \mathrm{C}$. Figure $7 \mathrm{c}$ shows relatively higher activity retention in lower temperature region $\left(30-50^{\circ} \mathrm{C}\right)$, however when the temperature further increased, power output greatly decreased indicating the decrease of enzyme activity. The immobilized enzymes showed a higher enzyme activity among $45-60{ }^{\circ} \mathrm{C}$ with an optimum temperature at $55^{\circ} \mathrm{C}$. In general, the immobilized enzyme possessed high activity in a broader temperature range, enabling it a desirable material for enzymatic biofuel cells application and many other fields.

\subsection{Electrochemical Behavior of the Lac/BC/c-MWCNTs Electrode}

As shown in Figure 8a, the CVs of the BC/c-MWCNTs/Lac electrode were absent, whereas a pair of prominent redox peaks (at $0.74 \mathrm{~V}$ and $0.11 \mathrm{~V}$, respectively) can be observed [32], which was attributed to the redox reaction of the Lac immobilized on the c-MWCNTs. This showed the good coupling between the enzymes and 3D BC/c-MWCNTs substrate. The redox of Lac on the electrode was a reversible and surface-confined process, which could be demonstrated by the linear relationship between redox currents and scan rate, as shown in Figure 8b. The bare 3D BC/c-MWCNTs electrode showed no catalytic action to $\mathrm{O}_{2}$ in comparison with that of BC/c-MWCNTs/Lac electrode.

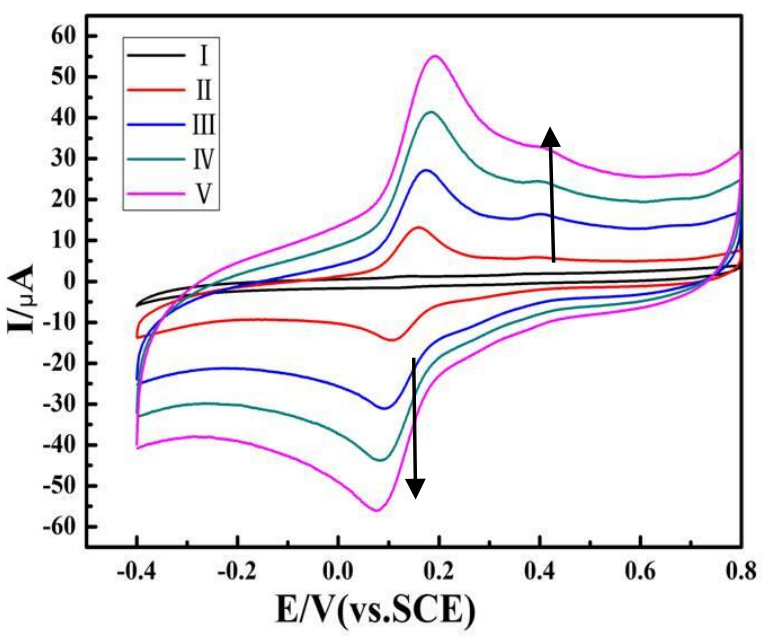

(a)

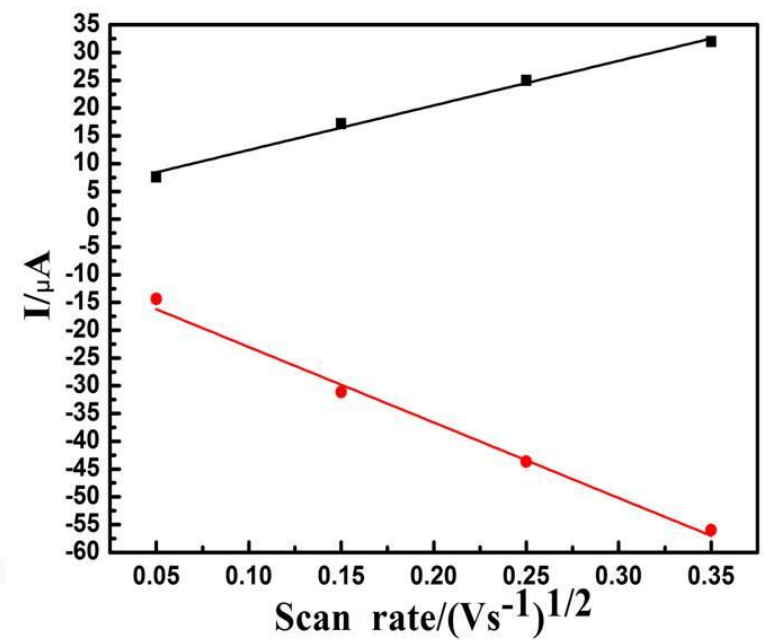

(b)

Figure 8. (a) Cyclic voltammograms of (I) the bare 3D BC/c-MWCNTs electrode and $\mathrm{BC} / \mathrm{c}-\mathrm{MWCNTs} /$ Lac electrode in a $0.1 \mathrm{M}$ acetic acid/sodium acetate buffer solution ( $\mathrm{pH}$ 5.5) at scan rates ( $\mathrm{mV} \mathrm{s}^{-1}$ ): (II) 50, (III) 150, (IV) 250, (V) 350; and (b) The inset is a plot of the oxidation and reduction peak currents $v s$. the scan rates.

\subsection{Performance of the Biofuel Cell}

The EBFCs were fabricated with a 3D BC/c-MWCNTs/Lac cathode and 3D BC/c-MWCNTs/GOD anode by GA crosslinking. As demonstrated in Figure 9a, the $\mathrm{E}_{\text {cell }}^{\text {ocv }}$ of the EBFC was approximately 
$0.64 \mathrm{~V}$. Through 30 days of open circuit voltage collected, a 51\% decrease of open circuit voltage was observed indicating relatively satisfactory stability, as shown in Figure 9b. Linear sweep voltammetry (LSV) was used to evaluate the electrochemical performance of enzymatic biofuel cell operating with glucose [33]. As shown in Figure 9c, the change of power density showed first increase and then a decrease with the decline of open circuit voltage whiles the open-circuit voltage was about $0.62 \mathrm{~V}$ which was relatively consistent with the biggest open circuit voltage in Figure 9a. The maximum current density was $0.29 \mathrm{~mA} / \mathrm{cm}^{3}$ and the maximum power density was $32.98 \mu \mathrm{W} / \mathrm{cm}^{3} \mathrm{implying}$ acceptable electric properties.
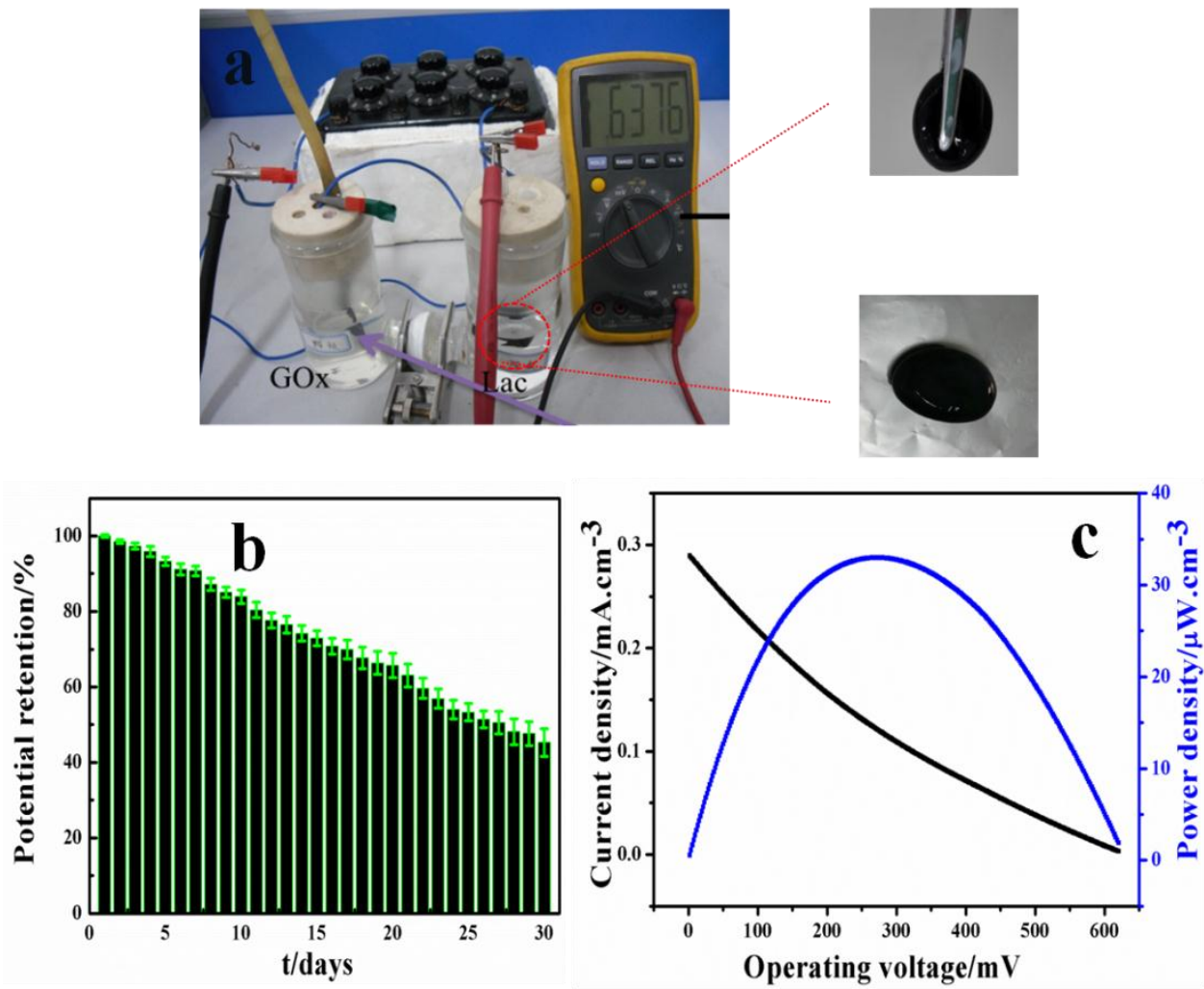

Figure 9. (a) The maximum open circuit voltage of the EBFCs; (b) The open circuit voltage from the EBFCs over 30 days; and (c) The power density curve of glucose $/ \mathrm{O}_{2}$ biofuel cell obtained by LSV in 0.1 $\mathrm{m}, \mathrm{pH}$ 5.5, HAc/NaAc buffer containing $50 \mathrm{mM}$ glucose, data were collected at $10 \mathrm{mV} \mathrm{s}{ }^{-1}$.

\section{Conclusions}

Lac and GOD were respectively immobilized on the BC/c-MWCNTs composite to prepare the cathode and anode of EBFCs. The nanotopographic surface of c-MWCNTs networks ensured snug anchoring of enzyme molecules by GA crosslinging. The influence of different concentrations, $\mathrm{pH}$ and temperature on the performance of EBFCs was investigated, and the optimum concentration, $\mathrm{pH}$ and temperature were $50 \mathrm{mM}, 5.5$, and $55^{\circ} \mathrm{C}$, respectively. The as-prepared EBFCs showed satisfactory electric properties. Our study demonstrated that the three-dimensional structure, controllable porosity as well as designable shape of BC could provide the application possibility in biofuel cell fields.

Acknowledgments: This research was financially supported by the Priority Academic Program Development of Jiangsu Higher Education Institutions, the National Natural Science Foundation of China (51203064 and 21201083), the Natural Science Fundation of Jiangsu Province, Industry-Academia-Research Joint Innovation Fund of Jiangsu Province (BY2014023-4, BY2014023-23 and BY2014023-29), Six talent peaks project in Jiangsu Province (2014-XCL001), the Department of Education in Anhui Province of China (2015LJRCTD001), the China Postdoctoral Science Foundation (2014M560391), the China Postdoctoral Science Foundation (2015T80496).

Author Contributions: All authors contributed equally to this work. 
Conflicts of Interest: The authors declare no conflict of interest.

\section{References}

1. Chen, Z.; Zhang, S.; Wu, F.; Yang, W.; Liu, Z.; Yang, M. Motion mode of poly (lactic acid) chains in film during strain-induced crystallization. J. Appl. Polym. Sci. 2015, 133, 42969-42978. [CrossRef]

2. Cooney, M.J.; Svoboda, V.; Lau, C.; Martin, G.; Minteer, S.D. Enzyme catalysed biofuel cells. Energy Environ. Sci. 2008, 1, 320-337. [CrossRef]

3. Yang, X.Y.; Tian, G.; Jiang, N.; Su, B.L. Immobilization technology: A sustainable solution for biofuel cell design. Energy Environ. Sci. 2012, 5, 5540-5563. [CrossRef]

4. Tsujimura, S.; Kamitaka, Y.; Kano, K. Diffusion-Controlled Oxygen Reduction on Multi-Copper Oxidase-Adsorbed Carbon Aerogel Electrodes without Mediator. Fuel Cells 2007, 7, 463-469. [CrossRef]

5. Prasad, K.P.; Chen, Y.; Chen, P. Three-dimensional graphene-carbon nanotube hybrid for high-performance enzymatic biofuel cells. ACS Appl. Mater. Inter. 2014, 6, 3387-3393. [CrossRef] [PubMed]

6. Minteer, S.D.; Atanassov, P.; Luckarift, H.R.; Johnson, G.R. New materials for biological fuel cells. Mater. Today 2012, 15, 166-173. [CrossRef]

7. Feng, W.; Ji, P.J. Enzymes immobilized on carbon nanotubes. Biotechnol. Adv. 2011, 29, 889-895. [CrossRef] [PubMed]

8. Vashist, S.K.; Zheng, D.; Al-Rubeaan, K.; Luong, J.H.T.; Sheu, F.S. Advances in carbon nanotube based electrochemical sensors for bioanalytical applications. Biotechnol. Adv. 2011, 29, 169-188. [CrossRef] [PubMed]

9. Gong, K.P.; Yan, Y.M.; Zhang, M.N.; Su, L.; Xiong, S.X.; Mao, L.Q. Electrochemistry and electroanalytical applications of carbon nanotubes: A review. Anal. Sci. 2005, 21, 1383-1393. [CrossRef] [PubMed]

10. Baughman, R.H.; Zakhidov, A.A.; De Heer, W.A. Carbon nanotubes-the route toward applications. Science 2002, 297, 787-792. [CrossRef] [PubMed]

11. Zhao, C.E.; Wang, Y.; Shi, F.J.; Zhang, J.R.; Zhu, J.J. High biocurrent generation in Shewanella-inoculated microbial fuel cells using ionic liquid functionalized graphene nanosheets as an anode. Chem. Commun. 2013, 49, 6668-6670. [CrossRef] [PubMed]

12. Klemm, D.; Schumann, D.; Udhardt, U.; Marsch, S. Bacterial synthesized cellulose-artificial blood vessels for microsurgery. Prog. Polym. Sci. 2001, 26, 1561-1603. [CrossRef]

13. Petersen, N.; Gatenholm, P. Bacterial cellulose-based materials and medical devices: Current state and perspectives. Appl. Microbiol. Biot. 2011, 91, 1277-1286. [CrossRef] [PubMed]

14. Jonas, R.; Farah, L.F. Production and application of microbial cellulose. Polym. Degrad. Stab. 1998, 59, $101-106$. [CrossRef]

15. Liang, H.W.; Guan, Q.F.; Zhu, Z.; Song, L.T.; Yao, H.B.; Lei, X.; Yu, S.H. Highly conductive and stretchable conductors fabricated from bacterial cellulose. NPG Asia Mater. 2012, 4, e19. [CrossRef]

16. Wang, B.; Li, X.; Luo, B.; Yang, J.; Wang, X.; Song, Q.; Chen, S.; Zhi, L. Pyrolyzed bacterial cellulose: A versatile support for lithium ion battery anode materials. Small 2013, 9, 2399-2404. [CrossRef] [PubMed]

17. Wang, M.; Anoshkin, I.V.; Nasibulin, A.G.; Korhonen, J.T.; Jani, S.; Jaakko, P.; Kauppinen, E.I.; Ras, R.H.A.; Olli, I. Modifying native nanocellulose aerogels with carbon nanotubes for mechanoresponsive conductivity and pressure sensing. Adv. Mater. 2013, 25, 2428-2432. [CrossRef] [PubMed]

18. Wan, Y.; Creber, K.A.M.; Peppley, B.; Bui, V.T. Chitosan-based solid electrolyte composite membranes I. Preparation and characterization. J. Membr. Sci. 2006, 280, 666-674. [CrossRef]

19. Ouyang, W.; Sun, J.; Memon, J.; Wang, C.; Geng, J.; Huang, Y. Scalable preparation of three-dimensional porous structures of reduced graphene oxide/cellulose composites and their application in supercapacitors. Carbon 2013, 62, 501-509. [CrossRef]

20. Feng, Y.; Zhang, X.; Shen, Y.; Yoshino, K.; Feng, W. A mechanically strong, flexible and conductive film based on bacterial cellulose/graphene nanocomposite. Carbohyd. Polym. 2012, 87, 644-649. [CrossRef]

21. Oikawa, T.; Ohtori, T.M. Production of cellulose from d-mannitol by acetobacter xylinum ku-1. Biosci. Biotechnol. Biochem. 1995, 59, 331-332. [CrossRef]

22. Kuo, C.H.; Chen, J.H.; Liou, B.K.; Lee, C.K. Utilization of acetate buffer to improve bacterial cellulose production by Gluconacetobacter xylinus. Food Hydrocoll. 2015, 53, 98-103. [CrossRef] 
23. Kiziltas, E.E.; Kiziltas, A.; Rhodes, K.; Emanetoglu, N.W.; Blumentritt, M.; Gardner, D.J. Electrically conductive nano graphite-filled bacterial cellulose composites. Carbohyd. Polym. 2016, 136, 1144-1151. [CrossRef] [PubMed]

24. Czaja, W.; Romanovicz, D.; Brown, R.M. Structural investigations of microbial cellulose produced in stationary and agitated culture. Cellulose 2004, 11, 403-411. [CrossRef]

25. Nandgaonkar, A.G.; Wang, Q.; Fu, K.; Krause, W.E.; Wei, Q.; Gorga, R.; Lucia, L.A. A one-pot biosynthesis of reduced graphene oxide (RGO)/bacterial cellulose (BC) nanocomposites. Green Chem. 2014, 16, 3195-3201. [CrossRef]

26. Torres, F.G.; Commeaux, S.; Troncoso, O.P. Biocompatibility of bacterial cellulose based biomaterials. J. Funct. Biomater. 2012, 3, 864-878. [CrossRef] [PubMed]

27. Parakalan, K.; Raed, H.; Mike, T. Modified cellulose morphologies and its composites; SEM and TEM analysis. Micron 2011, 42, 751-761.

28. Yan, Z.Y.; Chen, S.Y.; Wang, H.P.; Wang, B.A.; Jiang, J.M. Biosynthesis of bacterial cellulose/multi-walled carbon nanotubes in agitated culture. Carbohyd. Polym. 2008, 74, 659-665. [CrossRef]

29. Zhao, B.; Hu, H.; Yu, A.P.; Perea, D.; Haddon, R.C. Synthesis and characterization of water soluble single-walled carbon nanotube graft copolymers. J. Am. Chem. Soc. 2005, 127, 8197-8203. [CrossRef] [PubMed]

30. Zhou, T.; Chen, D.; Jiu, J.; Nge, T.T.; Sugahara, T.; Nagao, S.; Koga, H.; Nogi, M.; Suganuma, K.; Wang, X.; et al. Electrically conductive bacterial cellulose composite membranes produced by the incorporation of graphite nanoplatelets in pristine bacterial cellulose membranes. Express Polym. Lett. 2013, 7, 756-766. [CrossRef]

31. Rambo, C.R.; Recouvreux, D.O.S.; Carminatti, C.A.; Pitlovanciv, A.K.; Antonio, R.V.; Porto, L.M. Template assisted synthesis of porous nanofibrous cellulose membranes for tissue engineering. Mater. Sci. Eng. 2008, 28, 549-554. [CrossRef]

32. Gavaghan, D.J.; Myland, J.C.; Oldham, K.B. The effect of periodic modulation on the aperiodic current in linear-scan and cyclic voltammetries. J. Electroanal. Chem. 2001, 516, 2-9. [CrossRef]

33. Li, Y.; Wu, G.; Cong, R.; Qi, Z.; Yan, W.; Doherty, W.; Xie, K.; Wu, Y. Composite cathode based on doped vanadate enhanced with loaded metal nanoparticles for steam electrolysis. J. Power Sources 2014, 253, 349-359. [CrossRef]

(c) 2016 by the authors; licensee MDPI, Basel, Switzerland. This article is an open access article distributed under the terms and conditions of the Creative Commons by Attribution (CC-BY) license (http://creativecommons.org/licenses/by/4.0/). 